\title{
Meta
}

Journal des traducteurs

Translators' Journal

\section{Kadish, Doris Y. and Françoise Massardier-Kenney (Eds.) (1994): Translating Slavery. Gender and Race in French Women's Writing, 1783-1823, Kent (Ohio), the Kent State University Press, XVII, 346 p.}

\section{Paul St-Pierre}

Volume 42, numéro 3, septembre 1997

L'interprétation en langues des signes

URI : https://id.erudit.org/iderudit/004302ar

DOI : https://doi.org/10.7202/004302ar

Aller au sommaire du numéro

Éditeur(s)

Les Presses de l'Université de Montréal

ISSN

0026-0452 (imprimé)

1492-1421 (numérique)

Découvrir la revue

Citer ce compte rendu

St-Pierre, P. (1997). Compte rendu de [Kadish, Doris Y. and Françoise Massardier-Kenney (Eds.) (1994): Translating Slavery. Gender and Race in French Women's Writing, 1783-1823, Kent (Ohio), the Kent State University Press, XVII, 346 p.] Meta, 42(3), 589-592. https://doi.org/10.7202/004302ar d'utilisation que vous pouvez consulter en ligne. 
- KADISH, Doris Y. and Françoise MASSARDIER-KENNEY (Eds.) (1994): Translating Slavery. Gender and Race in French Women's Writing, 1783-1823, Kent (Ohio), The Kent State University Press, XVII, 346 p.

This rather unusual collection of critical essays and translations, reproduced here along with their originals, presents the works of three French women authors writing at the end of the eighteenth and at the beginning of the nineteenth centuries: Olympe de Gouges (1748-1793), Germaine de Staël (1766-1817) and Claire de Duras (1777-1828). One of the editors, Doris Y. Kadish, states the organizing principles behind the volume as follows (p. 2):

This volume focuses on translation, with specific emphasis on gender and race. In addition to the marginalization that they typically undergo in literary and historical studies, translation, gender, and race all entail the same kind of mediating process. Looking closely at what happens when translators translate and when writers treat gender and race, we can see that literature is not an objective expression of universal values, as has been traditionally assumed, but an ideological expression of local values. 
Marginalization, mediation and ideology are key concepts here, and, indeed, the various analyses and discussions of translating practices, both their own and those of others, all involve these notions in one way or another. Kadish continues (p. 3):

This volume argues, then, that the processes of mediation and ideology are essential for understanding translation and, accordingly, that translation should not be taken as rising above or standing outside of those processes. For translators in the twentieth century, as for writers or translators of an earlier time, ideological factors inevitably affect the treatment of issues of gender and race. [...] Rather than allowing silence to surround the problems encountered in producing translations of gender and race, this volume seeks instead to identify such problems and thereby increase our awareness of the constraints of ideology.

No translation is simply neutral or translates only its original; translation is rather, Françoise Massardier-Kenney, the co-editor of the volume, argues, a form of "linguistic mediation" between cultures, caught up in the power relations inscribed between and within cultures at any particular moment in time (p. 13). This is even more the case when the texts being translated deal with questions or persons marginalized in one or other of the contexts: "Any attempt to bring into another language or another culture the racial or cultural 'other' - women or persons of color — inevitably implicates the translatormediator in the exploitative conditions which link otherness to a specific power structure." (p. 14) The generalization being made here is probably not without some truth, but what seems to me problematic in the claim is preciscly its general nature, its lack of contextualization, for surely the 'implication in exploitative conditions' can take many, even contradictory, forms and requires nuanced and careful analysis of actual translations. Strong resistance to dominant structures through translation, or whole-hearted adoption of such structures, are very different strategies, very different possibilities for translators, though both may be considered cases of the 'implication' of translation in 'exploitative conditions.' And this point is of some interest in terms of the volume under review, since lack of contextualization, overgeneralization, or at the very least, too rapid generalization, tend to lessen the very definite interest the discussion of questions of gender and race has for the theory and practice of translation. Thus while Massardier-Kenney raises the question of the interconnection of gender and an approach to translation which emphasizes freedom, she does so on the basis of a mere two translations of a lone work, Uncle Tom's Cabin. A male translator produced a text at much further remove from the original than did a female translator, which leads the author to conclude: "These examples may or may not be representative, but they bring out the question of whether the range of the translator's textual intervention is linked to gender positions." (pp. 15-16) While the speculation is most certainly not without importance for translation studies, it remains speculation, unless the examples are in fact representative, and that precisely has not been shown. This same hastiness in drawing conclusions recurs in the discussion of the representation of women of color. In the translation of Claire de Duras's Ourika, the decision was taken on the part of the co-translators (Claire Salardenne and Françoise Massardier-Kenney) to "purposefully heighte[n] the eloquence of the black female character," to "purposefully effac[e] what sometimes appeared to them as the whining undertones of the character Ourika." (p. 16) In the awareness of the ideological implications which can underpin a translation strategy, their approach has something quite exemplary, but it also leaves me with a feeling of unease, since it seems predicated precisely on an unwillingness (probably more than an inability) to accept the other as different from oneself. Thus Massardier-Kenney describes in the following manner what led the translators to 'heighten' and 'efface': "Our project of presenting these authors as exemplary presences who gave voice to forgotten subjects (women and blacks) made the translators aware of the patronizing implications of presenting a woman and a colonized subject strictly as a victim." (p. 17) It 
is as if the decision was taken to erase anything which might offend a modern reader or lead her to consider the author as other than 'exemplary'. This seems not only to deny the existence of other, be they invalid, positions, but also to deny historicity and the shock of the confrontation of present and past. More than a reflection of one's own image is required if the social and ideological reality of the world is to be changed. Other cases of abusive generalization can also be cited: from the example of one woman translator (Phillis Wheatley) and her translation of one novel with an abolitionist theme, Kadish argues for the acknowledged "importance of women as active participants in achieving abolitionist goals, including the production of literary translations." (p. 38) This same translation "also indicates the importance that white abolitionists and persons of color working for abolition attributed to literature..." (p. 38) Kadish argues as well for Olympe de Gouges to be considered the very embodiment of the translator, although de Gouges did not herself translate, since like the translator she "constantly had to mediate between the official use of the French language and her own regional use of Occitan." (p. 38) Similarly, and it is precisely the 'similarity' between the different forms of mediation or translation which is problematic,

[t]he fact that her works were typically dictated rather than written, suggests a curious parallel between Gouges and Toussaint L'Ouverture, the black military and political leader of Santo Domingo, who also dictated speeches and statements that were rewritten and revised in standard French by secretaries. (pp. 38-39)

The comparison to Toussaint L'Ouverture here is of course not an innocent one, serving as it does to reinforce the author's argument, and one can wonder to what extent the use of dictation makes any significant link between de Gouges and the Haitian revolutionary. All forms of mediation become comparable here, and there is little which cannot be considered as such. (See pages 48-49, for example, where a form of the word 'mediation' occurs some nine times!) In the case of Germaine de Staël, Massardier-Kenney links together oral speech, gender and race in such a way as to evoke a causal connection: "Her emphasis on the oral rather than on the written made her particularly suited to accept cultures from Africa and to appreciate their oral traditions. Her partial exclusion from written discourse because of her gender allowed her to be inclusive racially..." (p. 136). It is necessary to ask oneself how convincing the argument is: if de Staël had not emphasized the oral, would her position towards slavery have been different? Are there other writers concerned about slavery, despite a lack of emphasis on the oral? Is the relation between the two truly causal, as presented here? The question of race and translation arises in the translation of Germaine de Staël, where the decision has to be made as to how to translate the words nègre and nègresse used by the author of the original to describe Africans. Such terms, Massardier-Kenney tells us,

had to be carefully thought out since they now have a negative connotation which was not necessarily present in the original French text. However, since the term Negro was endorsed by African Americans until recently, and since the translated text is obviously sited as an older text, not as a modernization, the term was kept. (p. 145)

This 'careful thinking out' seems not to have resolved the problem of the "negative connotation" the words now have and their endorsement "until recently" by African Americans. Furthermore, the footnote to the first occurrence of the word in the translation itself, justifies the use of "Negro" as follows: "Although the term is now perceived to have a negative connotation in general usage, some historians still use it, and Staël herself uses the word 'nègre', not the word 'noir."' (p. 329) The justification is now different, but hardly more convincing: which historians use "negro"?, but, more importantly, how is it 
possible to justify the use of a word within one linguistic system (late twentieth-century American English) by reference to a completely different system (late eighteenth-century continental French), especially after having already noted their difference ("a negative connotation which was not necessarily present in the original French text")? This lack of historical perspective is underscored by the discussion between Sharon Bell and Françoise Massardier-Kenney about their translations of Germaine de Staël. Constantly the point of reference is that of the modern-day translators, to the point that one of them remarks that she did not even consider resituating the characters in their context:

To look at Mirza and Ximeo [two characters in de Staël's story Mirza] in light of what was then current racist discourse, never hit me. I looked at it in the light of present-day racist discourse. That's why I couldn't really see what Staël accomplished in that story. (p. 177)

In this same discussion the contradictions of their own practices are made evident. After equating, ahistorically and somewhat abusively, the rewriting of a text through translation, complete with the removal of episodes and the addition of others - what they call 'radical translation' - with a 'male' position (whereas it is claimed that women translators show "a sense of deference to the authority of the text" (p. 179)), Bell and Massardier-Kenney go on to discuss the way in which the translation of Mirza was or could be radicalized, this in a translation in which additional elements not found in the original text are in fact supplied: "The French text does not use Jolof at all, but the translation does in an effort to restore the voice of the African characters." (p. 329) Is the radicalization carried out by 'male' translators, and characterized as 'offensive', in all cases so very different from that proposed here? Does the gender of the translator determine the value to be attached to a particular translation strategy? Similar questions arise from Doris Kadish's discussion of Ourika, by Claire de Duras. An anonymous 1829 translation of the text is discussed, in which an epigraph, from a woman writer, is added to the text. From this additional element, Kadish argues as follows:

And although the anonymity of the 1829 translation of course precludes any knowledge about the intentions or gender of the translator, the additional epigraph raises the distinct possibility that the translator may have been attentive to issues of gender and may have sought to capture or even enhance in the translation some of the resistant forces of the woman writer's original work. (p. 218)

The appeal here to intentions is an important marker of the basis of the whole discussion: origins, whether intentional or gendered, and most usually intentional because they are gendered, determine what is produced. Thus, what is characterized as added emphasis on "abolitionist tendencies" in the translation is considered to perhaps "also derive from the possible feminine gender of the translator." (p. 218) Speculation about the gender of the anonymous translator serves now to explain changes, considered as positive, made in the translation.

This volume has the merit of raising questions which must be of concern to any serious translator, notably with regards the nature of the mediation operated between cultures and its relation to power structures. If a somewhat more rigorous discussion of these questions would have been more useful, the volume, with the variety of discourses it includes - original texts, translations, theoretical discussions, discussions of translation strategies - has nevertheless the merit of leading the reader to look at translation as something more than a purely neutral, transparent practice. 